\section{p53-Mediated apoptosis is attenuated in Werner syndrome cells}

\author{
Elisa A. Spillare, ${ }^{1}$ Ana I. Robles, ${ }^{1}$ Xin Wei Wang, ${ }^{1}$ \\ Jiang-Cheng Shen, ${ }^{2}$ Chang-Eu Yu, ${ }^{3}$ \\ Gerard D. Schellenberg, ${ }^{3}$ and Curtis C. Harris ${ }^{1,4}$ \\ ${ }^{1}$ Laboratory of Human Carcinogenesis, National Cancer \\ Institute, National Institutes of Health, Bethesda, Maryland \\ 20892-4255 USA; ${ }^{2}$ Department of Pathology, University of \\ Washington, Seattle, Washington 98195-7705 USA; ${ }^{3}$ Geriatric \\ Research Education and Clinical Center (182B), Veterans \\ Affairs Puget Sound Health Care System, Seattle Division, \\ Seattle, Washington 98108 USA.
}

The WRN DNA helicase is a member of the DExH-containing DNA helicase superfamily that includes XPB, XPD, and BLM. Mutations in WRN are found in patients with the premature aging and cancer susceptibility syndrome known as Werner syndrome (WS). p53 binds to the WRN protein in vivo and in vitro through its carboxyl terminus. WS fibroblasts have an attenuated p53mediated apoptotic response, and this deficiency can be rescued by expression of wild-type WRN. These data support the hypothesis that p53 can induce apoptosis through the modulation of specific DExH-containing DNA helicases and may have implications for the cancer predisposition observed in WS patients.

Received February 12, 1999; revised version accepted April 21, 1999.

Werner syndrome (WS) is a rare autosomal disorder characterized by premature aging and early onset of age-related diseases including malignant neoplasms (Epstein et al. 1966; Goto et al. 1996). Cultures of WS cells show evidence of increased chromosomal instability including reciprocal translocations, inversions, and deletions (Thweatt and Goldstein 1993). Mutations in the WS gene $(W R N)$ are found in patients exhibiting the clinical symptoms of WS (Goto et al. 1997; Yu et al. 1997). The majority of WRN mutations result in impaired nuclear localization of the protein (Matsumoto et al. 1997). The WRN gene encodes a $3^{\prime} \rightarrow 5^{\prime}$ DNA helicase which belongs to the DExH-containing DNA helicase superfamily which includes XPB, XPD, and BLM (Ellis 1997). Although WRN has both ATP-dependent $3^{\prime} \rightarrow 5^{\prime}$ DNA helicase (Gray et al. 1997) and $3^{\prime} \rightarrow 5^{\prime}$ exonuclease activities (Huang et al. 1998; Shen et al. 1998), the role of WRN in DNA synthetic processes remains to be established. The WRN promoter is regulated by two different tumor suppressor gene products. Overexpression of the $\mathrm{Rb}$ protein can up-regulate the WRN promoter, whereas

[Key Words: DNA helicase; XPB; XPD; p53 carboxy-terminal domain] ${ }^{4}$ Corresponding author.

E-MAIL Curtis_Harris@nih.gov; FAX (301) 496-0497. overexpression of p53 can down-regulate $W R N$ promoter activity (Yamabe et al. 1998).

The tumor suppressor gene product p53 plays a critical role in maintaining the genomic integrity of mammalian cells (Lane 1992). The ability of p53 to induce apoptosis is thought to be an important factor for its tumor suppressor function (Levine 1997). p53 can both bind to XPB and XPD and modulate their DNA helicase activities in TFIIH (Wang and Harris 1996). The binding is mediated through the carboxyl terminus of p53 and the helicase motif III of XPB (Wang et al. 1995). Fibroblasts from cancer-prone individuals of xeroderma pigmentosum (XP) complementation groups $\mathrm{B}$ or $\mathrm{D}$ are deficient in their ability to undergo p53-mediated apoptosis (Wang et al. 1996).

Because the XPB and XPD helicases are important factors involved in p53 function, we hypothesized that another DNA helicase, WRN, also may be a target for $\mathrm{p} 53$. We propose that p53 binds to WRN and triggers apoptosis. To investigate this hypothesis, we performed immunoprecipitation experiments to examine the binding capabilities of $\mathrm{p} 53$ and WRN and to map the potential binding sites of WRN to p53. We developed a strategy using microinjection of wild-type p53 and WRN expression vectors into normal and WS primary human fibroblasts to examine the p53 apoptotic pathway in these cells. The common feature of XP-B, XP-D, and WS patients being cancer prone can be explained by defects of this p53-mediated apoptotic pathway.

\section{Results}

Binding of p53 to WRN in vivo and in vitro

To examine if p53 binds to WRN in vivo, we immunoprecipitated WRN followed by Western blotting of p53. A replication-defective adenovirus containing wild-type p53 was used to infect the p53 null lung carcinoma cell line Calu-6 at an m.o.i. of 1.3. As shown in Figure 1A, a WRN-specific polyclonal antibody coimmunoprecipitates p53 from p53-expressing cells (lane 4). This binding is blocked by the corresponding peptide used for producing the anti-WRN antibody (lane 5). Three p53 mutants (C175H, R249S, or R273H) that correspond to hot spot mutants found in human cancer (Hollstein et al. 1991) were each also transiently expressed in Calu- 6 cells. All three p53 mutants bind to WRN with the $\mathrm{C} 175 \mathrm{H}$ and $\mathrm{R} 273 \mathrm{H}$ mutants binding with a greater affinity when compared with the R249S mutant (Fig. 1B, lanes 2-4). The reduced binding to the R249S mutant is interesting, as this particular mutant was not capable of down-regulating the WRN promoter (Yamabe et al. 1998).

GST-p53 fusion constructs were used to determine the domains of p53 that bind to $\left[{ }^{35} \mathrm{~S}\right]$ methionine-labeled in vitro-translated WRN. Whereas a full-length p53 (1393 amino acids) and an amino-terminal deletion mutant (155-393 amino acids) bind efficiently to WRN in vitro, a carboxyl-terminal deletion mutant (1-293 amino acids) displayed minimum binding (Fig. 1C). No detect- 
Spillare et al.

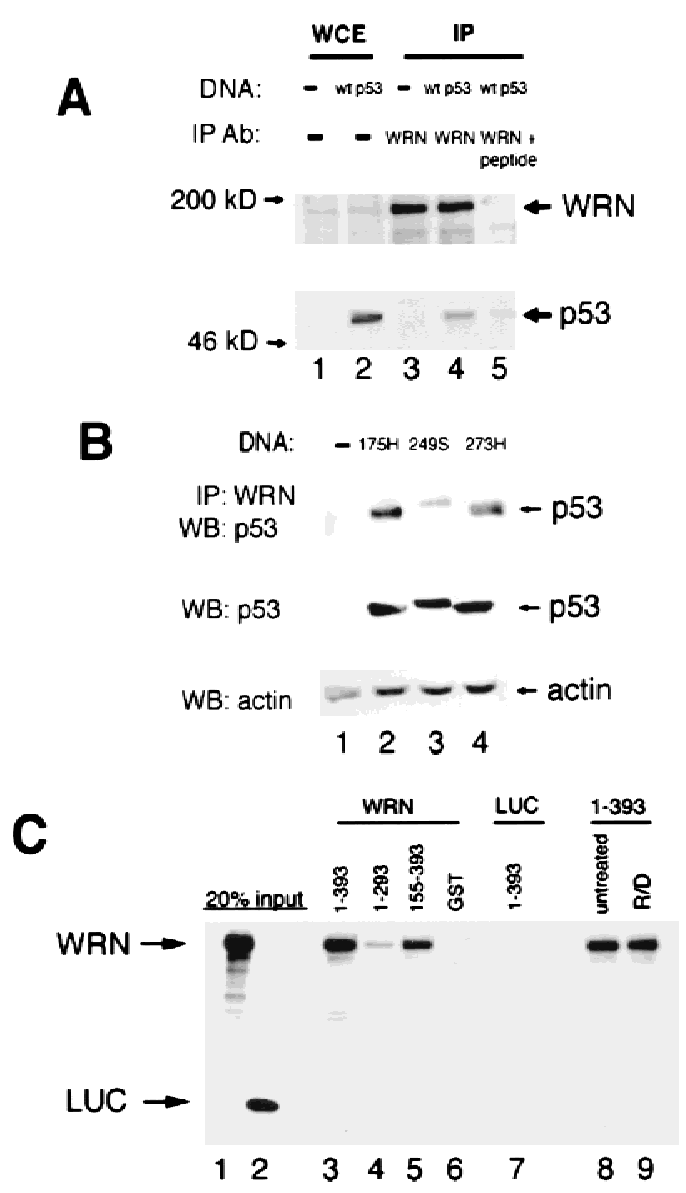

Figure 1. p53 and WRN bind both in vitro and in vivo. $(A)$ Calu-6 cells (p53 null) were infected with wild-type p53 adenovirus (lanes 2,4,5). Uninfected cells were used as negative controls (lanes 1,3). Protein lysates were immunoprecipitated with either anti-WRN $($ lanes 3,4$)$ or a peptide-blocked anti-WRN antibody (lane 5). Whole cell extract (WCE) $(50 \mu \mathrm{g})$ was loaded (lanes 1,2) as controls. (Top) The WRN protein migrating slightly larger than the $200 \mathrm{kD}$ protein marker; (bottom) the p53 protein. $(B)$ Calu- 6 cells were transfected with amino acid $175 \mathrm{H}$ (lane 2), 249S (lane 3), or 273H (lane 4) mutant p53 expression vectors. Untransfected cells were used as negative controls (lane 1). (Top) Mutant p53 proteins comigrating from lysates immunoprecipitated with anti-WRN antibody. WCEs $(20 \mu \mathrm{g})$ were loaded straight onto the gel and probed for either p53 (middle) or actin (bottom) to illustrate equal expression and loading of the proteins. (C) GST-p53 fusion proteins were incubated with in vitro-translated WRN protein (lanes 3-5) or luciferase (lane 7) to determine the binding specificity of p53 and WRN proteins. Full-length p53 (lane 3), carboxyl terminus (lane 4), or amino terminus deletion (lane 5) mutants show binding to the WRN protein. GST alone (lane 6) does not bind to WRN. Full-length p53 does not bind to luciferase (LUC) (lane 7). Treatment with R/D (RNase/DNase) (lanes 8,9) does not affect the binding. (Lanes 1,2) A $20 \%$ input of the WRN and luciferase proteins, respectively.

able binding was observed between WRN and GST alone or between the full-length p53 and GST-luciferase (Fig. $1 \mathrm{C}$, lanes 6,7). Treatment with RNase and DNase did not affect binding, indicating that the binding complex is not mediated through single-stranded DNA or RNA (Fig.
1C). Therefore, the WRN protein binds to the carboxyl terminus of p53, which also is the binding site of the DExH family-related DNA helicases XPB and XPD (Wang et al. 1995).

\section{p53-Mediated apoptosis is attenuated in WS fibroblasts}

To examine if p53-mediated apoptosis was attenuated in the WS cells, primary fibroblasts from one normal and three WS individuals were chosen based on the donor's age. Because the WS fibroblasts display a characteristic of premature aging/accelerated senescence in vitro, the population doublings (PDs) and the number of senescent cells, assessed by senescence-associated $\beta$-galactosidase (SA $\beta$-gal) activity (Dimri et al. 1995), were determined each time the cells were passaged. Consistent with previous findings (Thweatt and Goldstein 1993), cells from WS individuals underwent senescence at an earlier PD than did normal fibroblasts (Fig. 2A,B).

Then, we compared p53-mediated apoptosis in WS ver-

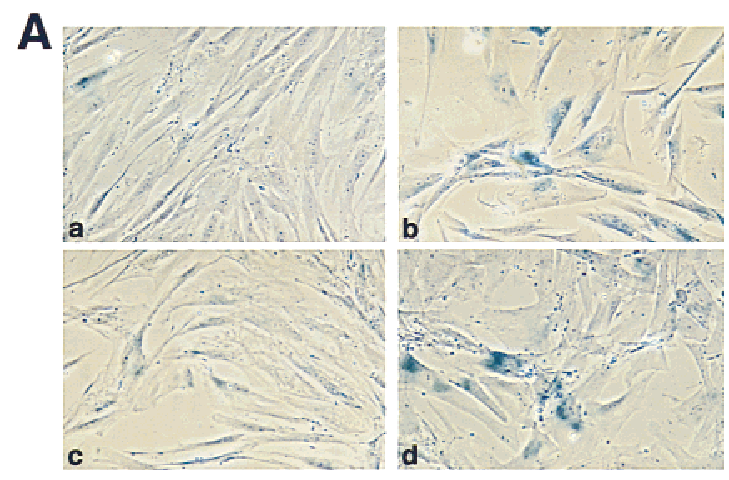

B

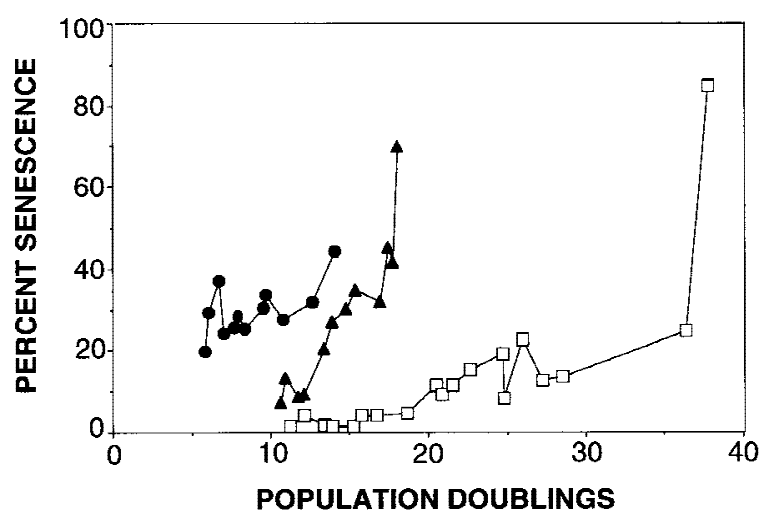

Figure 2. Rapid senescence of WS fibroblasts. $(A)$ For each microinjection experiment, cells were fixed and stained for SA $\beta$-gal activity for 12-18 hr. Positively stained cells for GM08402 normal fibroblasts at an early PD of $6.2(A)$ and a late PD of 24.4 $(B)$ are shown $(a, b)$. AG12797 fibroblasts at an early PD of $6.7(C)$ and late PD of $14(D)$ are shown $(c, d)$. (B) PDs were determined as described. The percent of senescent cells for normal fibro-

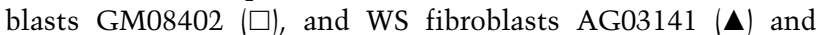
AG12797 (-) was plotted against the PDs. 
sus normal human fibroblasts. Increased expression of wild-type p53 in normal fibroblasts (GM08402) via microinjection of a CMV-driven expression vector resulted in an average of $22 \%$ apoptosis at $24 \mathrm{hr}$ (Fig. 3A). The amount of cDNA injected into these cells is equivalent to 10 copies of plasmid per cell. The typical features of apoptosis observed included cytoplasmic blebbing, chromatin condensation, and nuclear fragmentation. An in situ terminal deoxynucleotidyl transferase labeling assay (TUNEL) confirmed that these morphological changes were markers of apoptosis (data not shown). Minimum apoptosis $(2 \%)$ was observed in normal fibroblasts $24 \mathrm{hr}$ after microinjection with a CMV-driven green fluorescent protein (GFP) expression vector. This is a typical response of normal primary fibroblasts from several donors following microinjection of a p53 expression vector (Wang et al. 1996; Elmore et al. 1997).

However, when the fibroblasts from three different WS individuals (AG03141, AG12797, AG00780) were micro- injected with the wild-type $p 53$ expression vector, there was a statistically significant reduction in the percentage of apoptotic cells from all three WS individuals (Fig. 3A; Table 1).

This reduction was not due to the aging process associated with WS, because normal fibroblasts (AG05247) from an 87-year-old individual undergo p53-mediated apoptosis at the normal rate (Table 1). Furthermore, the shortened replicative life span of the WS cells does not appear to affect this rate because the WS fibroblasts showed an attenuated p53-mediated apoptosis even at low PDs, when the WS cells were replicating and not senescent (Fig. 3B).

Time course studies showed a persistent reduction in the amount of p53-mediated apoptosis in WS fibroblasts, compared with normal fibroblasts (Fig. 3C). The time course also shows an increase of apoptosis ( $80 \%$ at $72 \mathrm{hr}$ ) for the normal fibroblasts. To examine the cell cycle status of all cells overexpressing wild-type p53, the cells
A

$$
\text { cDNA: }
$$
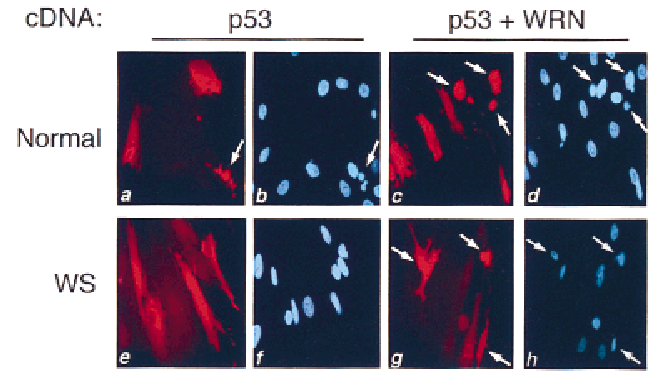

C

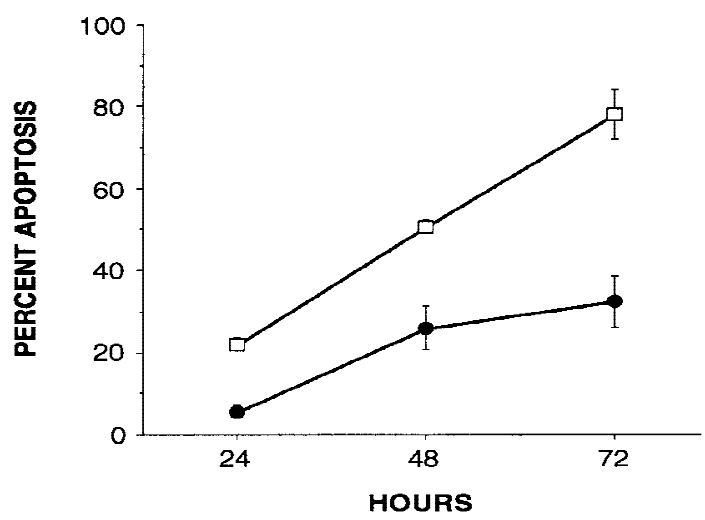

B

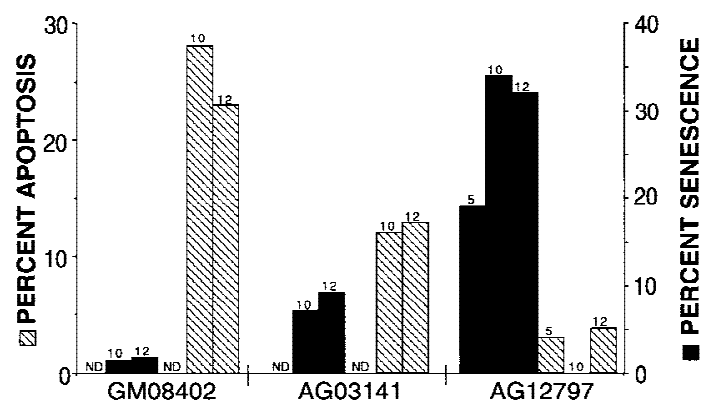

D

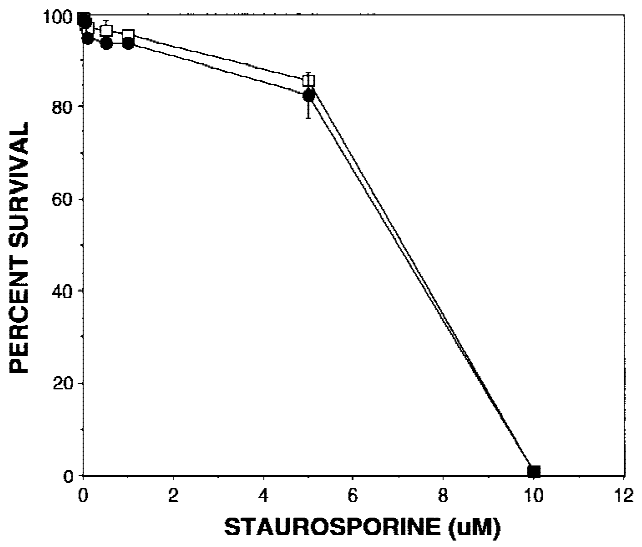

Figure 3. p53-mediated apoptosis in normal and WS fibroblasts. $(A)$ Both normal $(a, b)$ and WS fibroblasts, AG00780 $(e, f)$, were microinjected with $200 \mathrm{ng} / \mu \mathrm{l}$ wild-type p53 expression vector. Cells were fixed $24 \mathrm{hr}$ postmicroinjection and stained for p53 (a,e); nuclei were stained with DAPI $(b, f)$. Both GM08402 $(c, d)$ and WS (AG00780) $(g, h)$ fibroblasts were then microinjected with $100 \mathrm{ng} / \mu \mathrm{l}$ wild-type p53 plus $100 \mathrm{ng} / \mu \mathrm{l}$ WRN. Cells were fixed at $24 \mathrm{hr}$ and stained for p53 $(c, g)$; nuclei were stained with DAPI $(d, h)$. $(B)$ The percent apoptosis vs. percent senescence were determined for specific PDs. PDs of 5, 10, and 12 are shown and indicated at top of bars. Data presented were compiled from microinjection experiments (see Fig. 3A). (Hatched bars) Percent apoptosis; (solid bars) percent senescence. Results for normal (GM08402) and WS (AG03141, AG12797) fibroblasts are shown. (C) Normal (GM08402, $\square$ ) and WS fibroblasts (AG12797, O) were microinjected with the wild-type p53 expression vector. Cells were fixed and stained for p53 protein, and the nuclei stained with DAPI at 24,48 , and $72 \mathrm{hr}$. The number of apoptotic cells was calculated for each time point and results are graphed. (D) Normal (GM08402, $\square$ ) and WS (AG00780, @) fibroblasts were treated with staurosporine for 24 hr. Cells were stained as described in Materials and Methods. The percentage of dead cells was calculated as the number of Annexin V-positive cells/total number of cells. Three independent experiments were performed in $C$ and $D$. 
Spillare et al.

Table 1. p53-mediated apoptosis in WS fibroblasts

\begin{tabular}{|c|c|c|c|c|c|}
\hline \multirow[b]{2}{*}{ Cell donors ${ }^{\mathrm{a}}$} & \multirow{2}{*}{$\begin{array}{l}\text { Donor } \\
\text { age } \\
\text { (years) }\end{array}$} & \multirow{2}{*}{$\begin{array}{c}\text { Population } \\
\text { doubling } \\
\text { (range) }\end{array}$} & \multicolumn{3}{|c|}{ Percent induced apoptosis ${ }^{\mathrm{b}, \mathrm{c}}$} \\
\hline & & & $\begin{array}{l}\text { p53 } \\
(n)\end{array}$ & $\begin{array}{c}\mathrm{p} 53+\mathrm{WRN} \\
(n)\end{array}$ & $\begin{array}{c}\text { caspase-1 } \\
(n)\end{array}$ \\
\hline Normal (GM08402) & 32 & $9-38$ & $22 \pm 7(21)$ & $25 \pm 8(3)$ & $52 \pm 2(3)$ \\
\hline Normal (AG05247) & 87 & N.D. & $17 \pm 1(3)$ & N.D. & N.D. \\
\hline WS (AG03141B) & 29 & $10-18$ & $12 \pm 7^{\star}(14)$ & $22 \pm 5(3)$ & N.D. \\
\hline WS (AG12797A) & 36 & $5-14$ & $6 \pm 6^{\star}(13)$ & $20 \pm 2(3)$ & $48 \pm 5(3)$ \\
\hline WS (AG00780) & 59 & N.D. & $13 \pm 9^{\star \star}(4)$ & $24 \pm 9(3)$ & N.D. \\
\hline
\end{tabular}

(N.D.) Not determined.

a(Normal) National Institute of General Medical Sciences repository number; (WS) NIA aging cell repository number.

${ }^{b}$ Mean \pm S.D. $(n)$ Number of microinjection experiments.

${ }^{c}$ Student's $t$-test $\left({ }^{\star}\right) P<0.0001 ;\left({ }^{\star \star}\right) P=0.023$.

were subsequently labeled with BrdU. Whereas $\sim 35 \%$ of normal cells (GM08402) and 50\% of WS cells (AG00780) were positive for BrdU labeling, no BrdU labeling was seen in any p53-positive cells (data not shown). All normal (GM08402) and WS (AG00780) fibroblasts that were p53 positive were arrested in $\mathrm{G}_{1}$.

However, fibroblasts from both normal (GM08402) and WS (AG12797) individuals were still capable of undergoing apoptosis following microinjection of a caspase- 1 expression vector, a Ced-3 mammalian homolog capable of inducing apoptosis (Table 1; Wang et al. 1994). Thus, WS fibroblasts are capable of undergoing apoptosis and the reduction observed above may be specific for a p53-mediated pathway.

To examine if normal and WS fibroblasts were equally sensitive to a p53-independent cell death inducer, the cells were treated with staurosporine for $24 \mathrm{hr}$. At all doses $(0-10 \mu \mathrm{M})$, there was a similar rate of death for both cell types. The rate of cell death was determined by Annexin $\mathrm{V}$ staining. At the highest dose $(10 \mu \mathrm{M})$, there were no viable cells for either cell type. At $5 \mu \mathrm{M}$, there was $14 \%$ cell death for the normal cells and $17 \%$ for the WS cells.

\section{Expression of WRN can rescue deficiency} in p53-mediated apoptosis

To determine if this defect in p53-mediated apoptosis could be rescued by wild-type WRN, a WRN expression vector was comicroinjected with the wild-type p53 expression vector into WS cells. Immunocytochemical analysis showed that both proteins were expressed (data not shown). The level of p53-mediated apoptosis was restored to normal levels in the WS fibroblasts from each of the three donors (Fig. 3A; Table 1). Microinjection of the WRN cDNA alone was not sufficient to induce apoptosis. Expression of the WRN cDNA in normal fibroblasts (GM08402) resulted in only 3\% apoptosis, whereas there was $3 \%$ and $0 \%$ apoptosis for WS cells, AG03141 and AG12797, respectively. To determine if this correction was specific for the WRN gene or if any helicase can correct the attenuated apoptotic response, either wild-type p53 alone or the combination of $p 53$ and $X P D$ expression vectors was microinjected into normal
(GM08402) and WS (AG00780) cells. For p53 alone, 22\% of normal cells were apoptotic at $24 \mathrm{hr}$ and the addition of XPD did not alter this percentage. In WS cells, the microinjection of p53 alone induced $10 \%$ apoptosis at $24 \mathrm{hr}$, whereas p53 plus XPD resulted in $11 \%$ apoptosis. These data are genetic evidence that WRN contributes to $\mathrm{p} 53$-mediated apoptosis.

\section{Discussion}

In this report we have shown that WRN binds to p53 in vivo and that the binding site on p53 is located at its carboxyl-terminal region. Moreover, fibroblasts from WS individuals display an attenuated ability to undergo p53-mediated apoptosis that can be restored by expression of the wild-type WRN gene. This deficiency in p53-mediated apoptosis is not the result of either the normal in vivo aging or in vitro senescence processes. Interestingly, the carboxyl-terminal domain (CTD) of p53 is necessary for the physical interaction with WRN as well as with the XPB or XPD DNA helicase (Wang et al. 1995). Because the CTD can directly bind to XPB and induce apoptosis that is independent of p53 transactivation activity (Wang et al. 1996), we have proposed that the CTD may be involved in apoptosis by binding to and modulating the activity of DNA helicases that are required for controlling genomic stability (Wang et al. 1996). Consistent with this hypothesis are the results reported here indicating that another member of the DNA helicase family, WRN, also may be a downstream target in p53-mediated apoptosis.

WRN is a homolog to Xenopus laevis FFA-1, a DNA helicase that is required for the formation of replication foci during DNA replication (Yan et al. 1998). WRN also is a homolog of Escherichia coli RecQ and Saccharomyces cerevisiae SGS1, both of which are DNA helicases (Watt et al. 1996; Yamagata et al. 1998). Similar to human WS cells, the sgs1 mutation also reduces the average life span of yeast cells (Watt et al. 1996), and this phenotype appears to be associated with hyper-recombination, a possible role for genomic instability. Recently, WRN was shown to replace SGS1 to suppress hyper-recombination in a yeast sgs1 mutant (Yamagata et al. 1998). Murine mutant WS embryonic stem cells show an increased sensitivity to topoisomerase type I and II inhibitors, which are involved in DNA replication (Lebel and Leder 1998). Although WS is characterized by the premature appearance of normal aging in young adults and the WS cells also are hyper-recombigenic (Yamagata et al. 1998), it is still unclear that the premature aging condition is a consequence for an increasing risk of cancer. Here we show that cells from WS individuals but not from normal aging individuals display a reduced response to p53-mediated apoptosis in the absence of senescence features. Because p53-mediated apoptosis is an important determinant for maintaining genomic stabil- 
ity and preventing tumorigenicity (Yonish-Rouach et al. 1991; Clarke et al. 1993; Lowe et al. 1993; Symonds et al. 1994), the increased risk of cancer associated with WS may be the result, in part, of attenuation of a p53-mediated apoptotic pathway. These results have additional clinical implications. Given the possibility that WRN, $\mathrm{XPB}$, and XPD are downstream in a p53-mediated apoptotic pathway, these DNA helicases may be novel molecular targets in cancer therapy.

\section{Materials and methods}

Plasmids

pC53SN encodes the human wild-type $p 53$ cDNA and was provided by B. Vogelstein (Johns Hopkins University, Baltimore, MD). pßactM10Z contains the intact murine caspase- $1 \mathrm{cDNA}$ fused to $\beta$-gal and was provided by J. Yuan (Harvard University, Cambridge, MA). pGreen-Lantern (GIBCO BRL) contains a GFP cDNA insert. WRN expression vector, WRNpbrca WT, encodes the wild-type WRN cDNA.

\section{Immunoprecipitation analysis and Western blotting}

Protein lysates were prepared $24 \mathrm{hr}$ post-transfection/infection by lysing cells in immunoprecipitation buffer $(50 \mathrm{~mm}$ Tris- $\mathrm{HCl}$ at $\mathrm{pH} 8.0,120 \mathrm{~mm}$ $\mathrm{NaCl}, 0.5 \% \mathrm{NP}-40$ ) for $30 \mathrm{~min}$ on ice. Total protein was immunoprecipitated with anti-WRN antibody (Santa Cruz) overnight at $4^{\circ} \mathrm{C}$. Bound proteins were electrophoresed on $8 \%$ SDS-polyacrylamide gels and electrophoretically transferred to Immobilon-P membrane (Millipore). Detection of proteins was done using anti-p53 CM-1 antibody (1:1000; Signet Labs) or anti-WRN antibody (1:500) followed by ECL (Amersham).

In vitro binding assays

Full-length WRN and luciferase proteins were translated in vitro with $\left[{ }^{35} \mathrm{~S}\right]$ methionine (NEN) using the TnT-coupled reticulocyte lysate system (Promega). Full length p53 (1-393 amino acids) and p53 deletion mutants (1-293 and 155-393 amino acids) were purified as described previously (Wang et al. 1995). Reactions were done in binding buffer (50 mм Tris at pH 8.0, $120 \mathrm{~mm} \mathrm{NaCl}, 1 \mathrm{~mm}$ EDTA, 1 mм DTT, and 0.5\% NP-40), with $2 \mu \mathrm{g}$ of GST fusion protein-coated agarose beads or GST control-coated beads and $5 \mu \mathrm{l}$ of WRN protein $(10 \mathrm{ng} / \mu \mathrm{l})$. DNase I and RNase pretreatment of WRN in parallel with untreated sample in DNase I/RNase buffer, followed by binding to GST-p53-1-393 was a control for binding through a DNA/RNA intermediate. Reactions went for $5 \mathrm{hr}$ at $4^{\circ} \mathrm{C}$. Beads were washed, denatured, and separated on a 7\% SDS-polyacrylamide gel with $1 \mu \mathrm{l}$ of denatured WRN and luciferase proteins (20\% input). The gel was fixed, rinsed, treated with a $24 \%$ solution of sodium salicylate, vacuum dried, and exposed to Biomax film (Kodak) at $-70^{\circ} \mathrm{C}$.

Cell culture and population-doubling analysis

Calu-6 cells were obtained from ATCC and grown in RPMI with 10\% fetal bovine serum (FBS). Primary normal human fibroblasts (GM08402) and WS fibroblasts (AG03141, AG12797, AG00780) were obtained from Coriell Cell Repositories and were grown in Ham's F-10 media with 15\% FBS.

PDs were determined for cultures each time they were passaged, using the following formula: $\log$ (no. of cells) $-[\log$ (no. of cells plated) $\times$ plating efficiency] $/ \log 2$. PD was divided by the number of days of growth to calculate PD per day.

SA $\beta$-gal analysis

Cells were fixed in $2 \%$ formaldehyde $/ 0.2 \%$ glutaraldehyde in PBS for 5 min and incubated at $37^{\circ} \mathrm{C}$ for $12-18 \mathrm{hr}$ with fresh SA $\beta$-gal stain solution containing $1.0 \mathrm{mg} / \mathrm{ml} \mathrm{X-gal} \mathrm{(Dimri} \mathrm{et} \mathrm{al.} \mathrm{1995).}$

Microinjection and immunocytochemical analysis

Cells were plated on glass coverslips 2-3 days prior to injection. Plasmid cDNA expression vector $(200 \mathrm{ng} / \mathrm{\mu l})$ was injected into the nuclei of cells using a glass microcapillary needle. This corresponds to $\sim 10$ plasmids per cell. Only cells with nonsenescent morphology were injected for all experiments.

For WRN expression, WRN antibody was the generous gift of L.
Guarente, and the protocol for immunostaining of Guarente and his coworkers was followed (Marciniak et al. 1998).

For p53 expression, cells were fixed with $4 \%$ paraformaldehyde in PBS for $10 \mathrm{~min}$ followed by methanol for $20 \mathrm{~min}$ at $24 \mathrm{hr}$ postmicroinjection. Coverslips were washed in PBS-plus (0.15\% glycine, 0.5\% BSA in PBS). p53 was detected using the anti-p53 CM-1 antibody (1:200) (Signet Laboratories) for $1 \mathrm{hr}$ at $37^{\circ} \mathrm{C}$. Anti-rabbit IgG conjugated to fluorescein or Texas Red (Vector Laboratories) was used (1:300) for $30 \mathrm{~min}$ at room temperature. For p53 and WRN comicroinjection analysis, $100 \mathrm{ng} / \mathrm{\mu l}$ of each plasmid cDNA was mixed together and microinjected. Cells were stained for $\mathrm{p} 53$ as described above. Nuclei were stained with DAPI. Apoptotic cells were scored by morphological changes, including cytoplasmic blebbing and nuclear condensation and/or fragmentation. BrdU was added $(15 \mu \mathrm{g} / \mathrm{ml})$ for the final $6 \mathrm{hr}$. Cells were fixed in acetone $/$ methanol (1:1) for $10 \mathrm{~min}$ followed by $1 \mathrm{M} \mathrm{HCl}$ for $30 \mathrm{~min}$. Following extensive washing, cells were incubated with anti-BrdU (1:50, Oncogene Science) plus anti-p53 as described above. For the GFP analysis, the p-Green lantern vector $(200 \mathrm{ng} / \mu \mathrm{l})$ was microinjected as above. Cells were fixed with $4 \%$ paraformaldehyde at $24 \mathrm{hr}$.

For caspase-1-mediated apoptosis, cells were fixed with $1 \%$ glutaraldehyde in PBS for $10 \mathrm{~min}$ and stained with $0.5 \mathrm{mg} / \mathrm{ml} \mathrm{X}$-gal for 12-18 hr at $37^{\circ} \mathrm{C}$. Nuclei were stained with DAPI.

Staurosporine experiments were done by adding concentrations of $0-10$ $\mu \mathrm{M}$ to cells plated on eight-well chamber slides. Cells were stained for Annexin V using the Apoptosis Detection Kit (Oncogene Science). Following staining, cells were postfixed and stained with DAPI. Annexinpositive cells were counted to determine the percentage of cell death either by apoptosis or necrosis.

\section{Acknowledgments}

We thank David Orren and Vilhelm Bohr for their generous gift of the AG05427 fibroblasts cells and Lawrence Loeb and Ashwini Kamath-Loeb for their helpful discussion and comments on the manuscript. Support from some of the work comes from grant AG12019 from the National Institute on Aging (NIA).

The publication costs of this article were defrayed in part by payment of page charges. This article must therefore be hereby marked 'advertisement' in accordance with 18 USC section 1734 solely to indicate this fact.

\section{References}

Clarke, A.R., C.A. Purdie, D.J. Harrison, R.G. Morris, C.C. Bird, M.L. Hooper, and A.H. Wyllie. 1993. Thymocyte apoptosis induced by p53-dependent and independent pathways. Nature 362: 849-852.

Dimri, G.P., X. Lee, G. Basile, M. Acosta, G. Scott, C. Roskelley, E.E. Medrano, M. Linskens, I. Rubelj, O. Pereira-Smith, M. Peacocke, and J. Campisi. 1995. A biomarker that identifies senescent human cells in culture and in aging skin in vivo. Proc. Nat1. Acad. Sci. 92: 93639367.

Ellis, N.A. 1997. DNA helicases in inherited human disorders. Curr. Opin. Genet. Dev. 7: 354-363.

Elmore, L.W., A.R. Hancock, S.F. Chang, X.W. Wang, S. Chang, C.P. Callahan, D.A. Geller, H. Will, and C.C. Harris. 1997. Hepatitis B virus $\mathrm{X}$ protein and $\mathrm{p} 53$ tumor suppressor interactions in the modulation of apoptosis. Proc. Natl. Acad. Sci. 94: 14707-14712.

Epstein, C.J., G.M. Martin, A.L. Schultz, and A.G. Motulsky. 1966. Werner's syndrome: A review of its symptomatology, natural history, pathologic features, genetics and relationship to the natural aging process. Medicine (Baltim.). 45: 177-221.

Goto, M., R.W. Miller, Y. Ishikawa, and H. Sugano. 1996. Excess of rare cancers in Werner syndrome (adult progeria). Cancer Epidemiol. Biomarkers Prev. 5: 239-246.

Goto, M., O. Imamura, J. Kuromitsu, T. Matsumoto, Y. Yamabe, Y. Tokutake, N. Suzuki, B. Mason, D. Drayna, M. Sugawara, M. Sugimoto, and Y. Furuichi. 1997. Analysis of helicase gene mutations in Japanese Werner's syndrome patients. Hum. Genet. 99: 191-193.

Gray, M.D., J.-C. Shen, A.S. Kamath-Loeb, A. Blank, B.L. Sopher, G.M. Martin, J. Oshima, and L.A. Loeb. 1997. The Werner syndrome protein is a DNA helicase. Nat. Genet. 17: 100-103.

Hollstein, M., D. Sidransky, B. Vogelstein, and C.C. Harris. 1991. p53 mutations in human cancers. Science 253: 49-53. 
Huang, S., B. Li, M.D. Gray, J. Oshima, I.S. Mian, and J. Campisi. 1998. The premature aging syndrome protein, WRN, is a $3^{\prime} \rightarrow 5^{\prime}$ exonuclease. Nat. Genet. 20: 114-116.

Lane, D.P. 1992. Cancer. p53, guardian of the genome. Nature 358: 1516.

Lebel, M. and P. Leder. 1998. A deletion within the murine Werner syndrome helicase induces sensitivity to inhibitors of topoisomerase and loss of cellular proliferative capacity. Proc. Nat1. Acad. Sci. 95: 13097-13102.

Levine, A.J. 1997. p53, the cellular gatekeeper for growth and division. Cell 88: 323-331.

Lowe, S.W., E.M. Schmitt, S.W. Smith, B.A. Osborne, and T. Jacks. 1993 p53 is required for radiation-induced apoptosis in mouse thymocytes. Nature 362: 847-849.

Marciniak, R.A., D.B. Lombard, F.B. Johnson, and L. Guarente. 1998 Nucleolar localization of the Werner syndrome protein in human cells. Proc. Natl. Acad. Sci. 95: 6887-6892.

Matsumoto, T., A. Shimamoto, M. Goto, and Y. Furuichi. 1997. Impaired nuclear localization of defective DNA helicases in Werner's syndrome. Nat. Genet. 16: 335-336.

Shen, J.-C., M.D. Gray, J. Oshima, A.S. Kamath-Loeb, M. Fry, and L.A. Loeb. 1998. Werner syndrome protein. J. Biol. Chem. 273: 3413934144.

Symonds, H., L. Krall, L. Remington, M. Saenz-Robles, S. Lowe, T. Jacks, and T. Van Dyke. 1994. p53-Dependent apoptosis suppresses tumor growth and progression in vivo. Cell 78: 703-711.

Thweatt, R. and S. Goldstein. 1993. Werner syndrome and biological ageing: A molecular genetic hypothesis. BioEssays 15: 421-426.

Wang, X.W. and C.C. Harris. 1996. TP53 tumour suppressor gene: Clues to molecular carcinogenesis and cancer therapy. Cancer Surv. 28: $169-196$.

Wang, L., M. Miura, L. Bergeron, H. Zhu, and J. Yuan. 1994. Ich-1, an Ice/ced-3-related gene, encodes both positive and negative regulators of programmed cell death. Cell 78: 739-750.

Wang, X.W., H. Yeh, L. Schaeffer, R. Roy, V. Moncollin, J.M. Egly, Z Wang, E.C. Friedberg, M.K. Evans, B.G. Taffe, V.A. Bohr, J.H. Hoeijmakers, K. Forrester, and C.C. Harris. 1995. p53 modulation of TFIIH-associated nucleotide excision repair activity. Nat. Genet. 10: $188-195$

Wang, X.W., W. Vermeulen, J.D. Coursen, M. Gibson, S.E. Lupold, K. Forrester, G. Xu, L. Elmore, H. Yeh, J.H.J. Hoeijmakers, and C.C. Harris. 1996. The XPB and XPD helicases are components of the p53-mediated apoptosis pathway. Genes \& Dev. 10: 1219-1232.

Watt, P.M., I.D. Hickson, R.H. Borts, and E.J. Louis. 1996. SGS1, a homologue of the Bloom's and Werner's syndrome genes, is required for maintenance of genome stability in Saccharomyces cerevisiae. Genetics 144: 935-945.

Yamabe, Y., A. Shimamoto, M. Goto, J. Yokota, M. Sugawara, and Y. Furuichi. 1998. Sp1-mediated transcription of the Werner helicase gene is modulated by Rb and p53. Mol. Cell. Biol. 18: 6191-6200.

Yamagata, K., J.-I. Kato, A. Shimamoto, M. Goto, Y. Furuichi, and H. Ikeda. 1998. Bloom's and Werner's syndrome genes suppress hyperrecombination in yeast sgs1 mutant: Implication for genomic instability in human diseases. Proc. Natl. Acad. Sci. 95: 8733-8738.

Yan, H., C.Y. Chen, R. Kobayashi, and J. Newport. 1998. Replication focus-forming activity 1 and the Werner syndrome gene product. Nat. Genet. 19: 375-378.

Yonish-Rouach, E., D. Resnitzky, J. Lotem, L. Sachs, A. Kimchi, and M. Oren. 1991. Wild-type p53 induces apoptosis of myeloid leukaemic cells that is inhibited by interleukin-6. Nature 352: 345-347.

Yu, C.E., J. Oshima, E.M. Wijsman, J. Nakura, T. Miki, C. Piussan, S. Matthews, Y.H. Fu, J. Mulligan, G.M. Martin, and G.D. Schellenberg. 1997. Mutations in the consensus helicase domains of the Werner syndrome gene. Werner's Syndrome Collaborative Group. Am. J. Hum. Genet. 60: 330-341. 


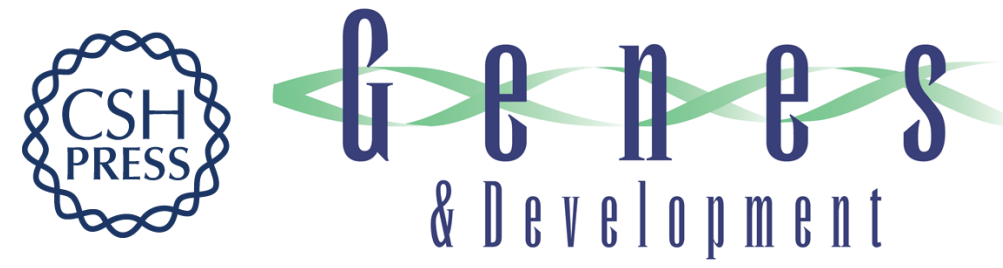

\section{p53-Mediated apoptosis is attenuated in Werner syndrome cells}

Elisa A. Spillare, Ana I. Robles, Xin Wei Wang, et al.

Genes Dev. 1999, 13:

References This article cites 29 articles, 11 of which can be accessed free at: http://genesdev.cshlp.org/content/13/11/1355.full.html\#ref-list-1

License

Email Alerting

Receive free email alerts when new articles cite this article - sign up in the box at the top Service right corner of the article or click here.

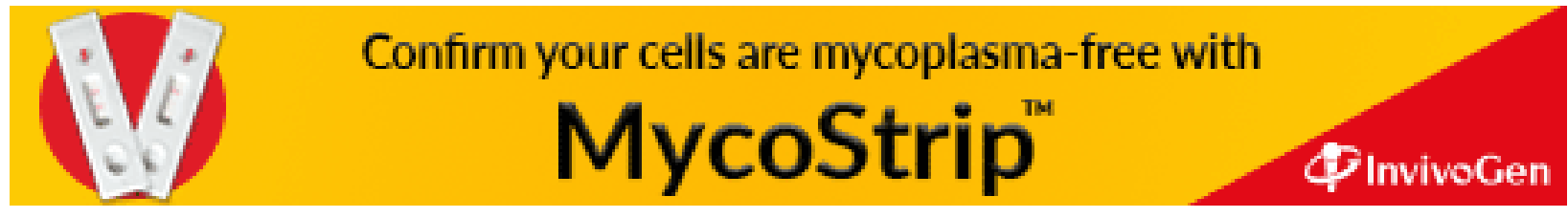

